\title{
GREAT POWER COMPETITION: LESSONS FROM THE PAST, IMPLICATIONS FOR THE FUTURE
}

\section{Alexander L. Vuving}

When we march into the future, the road is foggy and obscured. Our only light is the past which illuminates fragments of the paths we may take. The future is filled with countless possibilities, but not all are created equal. Some possibilities are more likely than others due to the structure of the field of possibilities. It is through the past that we can discern how the field of possibilities is structured.

This essay will mine the past for lessons about great power competition by examining the impact of human dynamics, technology, and geography on the rise and fall of the great powers, the balance of power among them, and the character of their relations. The history of great power competition dates back to the late 4th millennium BC, when the most powerful of the earliest states in the world vied for supremacy in Egypt and Mesopotamia, the world's most productive areas at that time. ${ }^{1}$ In the 52 centuries that followed, numerous factors have shaped the interaction among great powers, but the most consequential, and most permanent, are human dynamics, technology, and geography. This essay revolves around a number of key questions: What tips the balance of power among the great powers? Apart from the general balance of power, what are the key structures of great power relations? What shapes and changes these structures, and why?

The first three sections of this paper will discuss the impact of human dynamics, technology, and geography on great power competition. The lessons drawn from this discussion will inform the implications for the future, which will be addressed in the latter part of the paper. In this 
future-oriented part, I will focus on these major questions: Will great power competition continue in the future? What will perpetuate it, and what will arrest it? How do the key structures of great power relations shape the hegemonic contest of our time? What strategies are critical to winning that contest? Apart from the great powers, what emerging actors can cause profound changes and disrupt the balance of global power in the coming decades? I hope the discussion in this paper will light the path of great power competition for decades to come.

\section{IMPACT OF HUMAN DYNAMICS}

As with any human community, the fate of great powers hangs in significant part on the decisions made by its members, individually or collectively. Although great powers are highly complex organizations, the major decisions to steer their course have often been concentrated in the hands of a few people, much of the time even a single individual. As power was concentrated on a few people, their beliefs, personalities, preferences, and relationships disproportionately affected the course of the state they ruled. The personal ambition of an empire's founder invariably lay at the root of the empire's rise and expansion, which was also contingent on his talent, leadership skills, and vision. These personal factors of his successors, the influence of their advisors, family members, and friends, and the relations among the ruling factions would continue to play a large role in the lifeand death—of the empire.

The concentration of power on a few is itself a universal human dynamic. Sometimes it reflects the attraction of leadership and the practice of followership; sometimes it results from the coercive force of a few over the many; sometimes it is maintained by a "social contract" in which the rulers get more wealth and freedom in exchange for providing the ruled with security and prosperity; oftentimes it is a confluence of all three. The phenomenon of the great powers is itself the manifestation of this human dynamic at the international level. The more power is concentrated, the more it reflects the beliefs and desires, as well as the whims and caprices, of the powerful. 
Many countries in the past were regarded as the real estates of their rulers or the families of their rulers. As most people wanted to enlarge their own real estates, so did these rulers and their families. Sometimes, the cohesion and strength of a great power diminished significantly because it was divided up among the sons of its ruler after his death. This was the case, most glaringly, with the Carolingian empire and the Mongol empire. Sometimes, several countries were merged into a larger one through the marriage of their rulers. The emergence of Spain as a great power has its root in the marriage of Queen Isabella I of Castile and King Ferdinand II of Aragon (1469). A marriage of their rulers also united the Spanish and Portuguese empires in the Iberian Union (1580 - 1640). Marriage was the main way through which the House of Habsburg expanded their holdings and knit together the largest power in Europe during the 15 th and 16 th centuries.

The belief that a country is the property of its ruler, although widespread, was a specific case among the different beliefs about the right to own a land and the right to rule a people. These and other belief systems, which we call ideology, religion, superstition, or science, were indispensable and impactful in guiding the thoughts of people - rulers and ruled alike—on almost everything. Apart from its thought-guiding function, ideology (called religion when tied to one or more gods) always played an important role in beefing up and breaking up the cohesion and strength of the states in general and the great powers in particular. When the Arabs defeated both great powers of their time, the Persian empire of the Sassanids and the Byzantine empire, and created a new great power, the Rashidun Caliphate, they relied not only on the superiority of their military tactics and the talent of their generals, but also on the religious fervor of their combatants, the religious difference between the rulers and the populace of the Persian empire, and the religious oppression of the Byzantine empire against many of its citizens in the Levant and Egypt. ${ }^{2}$

The Arabs provide a glaring example not only of the impact of ideology but also of who I will call "system-changers." Examples of systemchangers abound throughout the history of the great powers. ${ }^{3}$ 


\section{System-Changers}

The Amorites, the Hurrians, the Kassites, the Phrygians, and the Aramaeans (21st - 11th centuries BC). Their nomadic lifestyle and tribal structures made them superior in terms of mobility and flexibility to the great powers of their time. Their migrations, infiltrations, and invasions led to the collapse of those great powers, but most adopted the civilizations of their adversaries afterward. The Amorites and the Hurrians later founded the ruling dynasties of three great powers: Assyria, Babylon, and Mittani. The language and alphabet of the Aramaeans became the common tongue of the Middle East by 500 BC.

The Yuezhi (Tokharians) and the Sakas (which meant "nomads" in Iranian). When these Indo-Iranian steppe peoples fled westward and southward in the 2nd and 1st centuries BC, they effectively merged the two hitherto independent systems of states, one in the Mediterranean, the Middle East, and the Indian subcontinent and another in East Asia, into a single system that included all states in the world at that time. The expansion of the Xiongnu drove the Yuezhi westward, who in turn pushed the Sakas southward. A branch of the Yuezhi settled in Bactria and founded the Kushan empire, which in its heyday in the 2 nd century AD stretched from the Aral Sea to the Indian Ocean and was one of the four great powers of that time, together with the Roman Empire, the Parthian empire, and the Han empire.

The Germanic peoples, most notably the Visigoths and the Vandals (4th - 5th centuries). Their rebellions and invasions contributed heavily to the collapse of the Western Roman Empire. Many of these people had been embedded in the Roman Empire as foederati (treaty-bound allied people), though their loyalty ultimately lay with their kings and nobles. Treated unfairly by the Romans, they revolted, led by the Germanic elements of the Roman Army, and founded new Germano-Roman states on the soil of the Roman Empire.

The Vikings and the Normans (9th -12 th centuries). These Nordic peoples excelled in mobility as sailors and founded several kingdoms scattered from the Atlantic to the Mediterranean. Their migrations were generally led by a coalition of warlords and individuals seeking opportunities for themselves and their followers. It was rare for a Norse or Norman head of state to lead an invasion, such as the case of William the Conqueror's invasion of England. This flexibility in leadership, combined with a nearly unmatched naval ability, allowed the Nordic peoples to severely hinder both the Byzantine and Carolingian empires, displace the Khazars as the dominant traders in the Pontic steppes, and establish numerous colonies from Greenland to Antioch.

Various Turkic groups such as the Pechenegs, the Oghuz, and the Karluks (10th - 11th centuries). Their migrations, military campaigns, and involvement in political affairs of the states they served massively disrupted the balance of power in the Middle East, Eastern Europe, Central Asia, and the Indian subcontinent. Among their exploits was driving the Byzantines out of Anatolia, embedding themselves in the Caucasus, toppling Persian powers such as the Samanids and Abbasids, and introducing Islam into Northern India. Their success can be attributed to their mobility and military excellence. Another advantage was the prevalence of Turkish mamluks in military positions, which allowed them to stage coups and revolts such as the Ghaznavid takeover of the Samanid empire. 


\section{System-Changers (continued)}

The European adventurers, most notably the Spanish conquistadors, the Portuguese traders, and the Russian pioneers (merchants, Cossacks, peasants), in the 16th -17 th centuries. While seeking fortune for themselves, they acquired territory in service of their state. Although many adventurers held strong ties to their sovereign, the limited communication between the two parties gave the adventurers significant leeway in their actions. The Portuguese displaced the Arabs as the dominant traders in the Indian Ocean and fundamentally changed warfare and politics in Japan during the critical Sengoku period. The conquistadors toppled both the powerful Aztec and Incan empires, while the Cossacks pushed Russian sovereignty as far as Kamchatka and warred with the Qing empire and various Mongol successor states.

The British East India Company, a joint-stock company with close ties to the British government. The company's private army in the 18th century played a large role in conquering India, thus securing monopoly trade rights for the company. The company governed the conquered territories until the Regulating Act of 1773. In the mid-19th century, the company was a driving force behind the two Opium Wars that marked the beginning of what the Chinese later called their "century of humiliation."

The Islamic fundamentalists in the late 20th and early 21st century (to be addressed below).

What these diverse communities, movements, and organizations have in common is that more than the secondary states in the international system, which have to take the system as it is, they are able to change the system, thanks largely to the extraordinary dynamism of their quest for opportunities, but less than the great powers, they are, for the moment, still unable to make the system, i.e., to stabilize it. Some, such as the Kushans and the Arabs, quickly crossed the threshold to become system-makers by building empires or influential states of their own. Others, such as the conquistadors, the Russian pioneers, and the British East India Company, engaged in a close relationship with a sovereign state to obtain government sanction and support. While they maintained a considerable room for independent actions, they were often the frontier forces that expanded the sphere of influence, even the territory, of their sovereign. Still others, such as the Amorites and the Kassites, captured existing states, replaced their ruling elite, and changed the character of these states.

In the post-Cold War period, when the United States remained the world's sole superpower, a debate broke out among scholars of international relations about the longevity of this unipolarity. Skeptics argued that 
it would not last long because sooner rather than later other major powers would gang up against the hegemon. ${ }^{4}$ Believers contended that America's global hegemony was there to stay because the immense power gap between the United States and the next biggest powers would both discourage and thwart any attempts at balancing it. ${ }^{5}$ As it turned out, the skeptics were somewhat right in their conclusion-U.S. unipolarity did not last longer than a quarter of a century — but wrong in their reasoning- the only weighty anti-American coalition was that of China and Russia, but this arrived late toward the end of the unipolar period. ${ }^{6}$ Both sides of the debate missed the mark because they ignored the role of the system-changers. The September 11, 2001 attacks on the Twin Towers in New York and the Pentagon by Islamic fundamentalists changed the world in an enormous way. The Bush administration immediately turned to a "global war on terror," which would consume much of Washington's foreign policy attention, energy, and spending for more than a decade. In the 15 years from 2001 to 2016, China, which presidential candidate Bush characterized as early as 1999 as the "strategic competitor" of the United States, enjoyed what its leaders recognized as a prolonged "strategic opportunity" during which it was able to quadruple its economic output, catapult from the sixth-largest to the second-largest economy in the world, and turn the South China Sea into a chokepoint it can control by building several large artificial islands on disputed reefs in the middle of the sea. ${ }^{8}$

Human dynamics that are highly consequential to great power competition often come in three forms. First, some actors that have previously been at the margins of the system or not even existed - the "new kids on the block" - now bring in enormous new energy created by their superior mobility, ideological fervor, or economic resources. Second, some actors get ahead of others due to major innovation in military technology and governance organization. Third, some actors acquire a vast amount of knowledge and skills by learning from the most advanced and from experiences of the past, and by integrating aspects of other cultures, which are beneficial, into their own. These new energies, innovations, learning, and integration invariably lie at the root of the rise of new great powers. On the other hand, great powers that lose energy, lack major innovations, and fail to learn from others and integrate new cultures are bound to diminish.

\section{IMPACT OF TECHNOLOGY}

Technology has two chief structural effects on great power competition: it can tip the balance of power and it can change the structure of the 
strategic game among the great powers. Technology is one of the few underlying factors that distinguish great powers from lesser states. Without superior technology, no actor can become a great power. However, rarely has the edge in a single technology tipped the balance among the great powers. One reason for this is the rapid diffusion of technology. When great powers are in intense competition with one another, a newly innovated and applied technology is quickly learned once it demonstrates some advantage. As a result, being the innovator of a major technology does not guarantee superiority; sometimes a quick learner who adds smaller innovations in accessories can beat the first innovator.

When technology tips the balance among great powers, what makes the difference is often one or more clusters of related technologies supported by socioeconomic and organizational factors. As warfare has often been the ultimate arbiter of success in international relations, besides the more general issues such as morale, communication, and logistics, great powers usually had to compete for higher mobility, firepower, and defense of military forces. The chariot, the sling, the composite bow, the horse saddle, the saddle stirrup, and the various types of armor had greatly enhanced these abilities in the agricultural age. So did their successors in the industrial age: the nuclear warhead, the cruise missile, the ballistic missile, the combustion engine, the submarine, and the missile defense system. Missile superiority can sometimes shift the balance between great powers, but what constitutes missile superiority is a combination of technological innovation, a robust economic base, and organizational prowess.

Perhaps the largest impact of technology on great power competition is that of nuclear weapons. They can change the structure of the strategic game between states and with it, the best strategies for the players and the stable outcomes of the game. Nuclear weapons do so by helping people to exceed the "overkill" threshold.

Prior to the nuclear age, most great powers saw their own predominance as the best option, their own subordination as the worst, a division of power as the second-best, and war as the second-worst, or third-best, option. We can express this preference order as $\mathrm{P}>\mathrm{D}>\mathrm{W}>\mathrm{S}$, where $\mathrm{P}$ stands for predominance, $\mathrm{D}$ for division of power, $\mathrm{W}$ for war, and $\mathrm{S}$ for subordination. When two players having this preference order engage in a strategic competition, they are locked in a situation called "prisoner's dilemma." This situation has a distinctive structure that renders the best strategy for each player invariably to "defect" - to pursue its self-interest regardless of whether the opponent will cooperate or not. This strategy 
corresponds with the stable outcome of the game, called "Nash equilibrium" after the mathematician John Nash, who has shown mathematically how the structure of a strategic game dictates the best strategies for the players and determines the stable outcomes of their game (Nash was awarded a Nobel Prize in economics 40 years later for this work). The stable outcome of the prisoner's dilemma, its only Nash equilibrium, is war when the players are competing great powers. The Greek historian Thucydides's comment on the war between the hegemonic contenders of his time and place, "It was the rise of Athens and the fear that this inspired in Sparta that made war inevitable," was a 5th-century BC statement of the prisoner's dilemma's Nash equilibrium. ${ }^{\text {? }}$

The structure of the prisoner's dilemma hinges on a key perception: nothing, including war, is worse than subordination. This perception was prevalent among the great powers of the past; indeed, the subordinated was guaranteed to lose everything most valued in life: honor, wealth, independence, freedom. Nuclear weapons upend this perception. Because of its "overkill" effect, war between nuclear-armed states can be worse than subordination. An all-out nuclear war between two great powers can destroy both. This perception structurally transforms a hegemonic contest from a "prisoner's dilemma" to a "chicken game."

In a great power competition structured as a chicken game, the best option for the players remains their own predominance and the secondbest option a sharing or division of power, but the worst option is war and the second-worst, or third-best, option is subordination $(\mathrm{P}>\mathrm{D}>\mathrm{S}>\mathrm{W})$. With the structure of the game transformed, the best strategy and stable outcome of the game are also changed. The most striking difference between the prisoner's dilemma and the game of chicken is the reverse of their stable outcomes. If war is inevitable in a great power competition structured as a prisoner's dilemma, peace is equally attainable in a great power competition structured as a game of chicken. There are three Nash equilibria in the game of chicken, corresponding to three stable outcomes and three sets of best strategies for the players. ${ }^{10}$ A game of chicken between two hegemonic contenders may result in either a division of power that both contenders more or less honor or the predominance of one of the contenders. The first hegemonic contest of the nuclear age, the "Cold War" between the Soviet Union and the United States, was so dubbed because it did not involve open warfare between the two great powers. Conforming with the Nash equilibria of the chicken game, the Cold War took the form of an extremely tense but relatively stable division of Europe, its 
central theater of contest, throughout the conflict and eventually resulted in U.S. hegemony when the Soviet Union imploded.

Recently, Professor Graham Allison of Harvard invoked Thucydides and coined the term "Thucydides Trap" to describe the inclination to war of great power competition. He raised the specter of war between the two hegemonic contenders of today and asked, "Can America and China escape Thucydides's trap?" But his thesis is misplaced at best because it is based on a fundamentally flawed assumption. It assumes that all cases of great power competition share a similar structure as illustrated by Thucydides's famous quote about the inevitability of war between Athens and Sparta. Hence it posits the existence of the Thucydides Trap where this does not exist: in games of chicken $(\mathrm{P}>\mathrm{D}>\mathrm{S}>\mathrm{W})$ such as the strategic rivalries between Portugal and Spain in the late 15th century and between the United States and the Soviet Union in the 20th century, in the "called bluff" game (a combination of the game of chicken and the prisoner's dilemma) between Britain and the United States in the early 20th century, and in the "concord" game $(\mathrm{D}>\mathrm{P}>\mathrm{S}>\mathrm{W})$ between Britain/France and Germany in the 1990s. ${ }^{11}$ Yet, these "peace" cases are treated as anomalies in the Thucydides Trap thesis, while the "war" cases are regarded as normal. ${ }^{12}$ In light of the strategic game structure, however, the "no war" outcomes of these rivalries are predicted perfectly by their Nash equilibria. The risks of war still exist in the games of chicken, but they lie in human errors, machinery defects, or other non-structural factors, not in the Thucydides Trap.

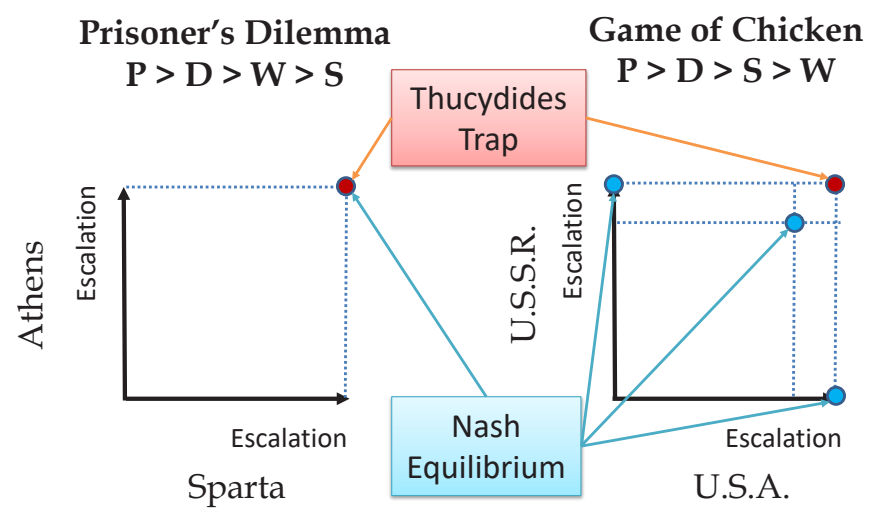

Figure 2.1. Strategy and Outcome of Great Power Competition 


\section{IMPACT OF GEOGRAPHY}

Nuclear weapons are not the only factor that can transform a prisoner's dilemma into a game of chicken. A contested region far from the core area of a great power can make this contender perceive the cost of subordination in that region smaller than the cost of war, especially if war can reach the core area. This perception- that war is worse than subordination-renders the competition over a remote region a game of chicken $(\mathrm{P}>\mathrm{D}>\mathrm{S}>\mathrm{W})$, not a prisoner's dilemma $(\mathrm{P}>\mathrm{D}>\mathrm{W}>\mathrm{S})$. The hegemonic contest between Portugal and Spain over the non-Christian world in the late 15th and early 16th centuries was a game of chicken because both great powers competed for areas far from their home territories and still largely unknown to them. The competition between the United States and the United Kingdom for supremacy in the Western Hemisphere in the late 19th and early 20th centuries was an asymmetric game, named "called bluff" by game theorists, in which Britain played chicken because the contested site lay far from its home while America played the prisoner's dilemma because Washington was ready to wage war to assert its primacy. Predicted by their Nash equilibria, both rivalries resulted in agreements on spheres of influence.

Like technology, geography can elevate a state into great power status, tip the balance of competition, and change the structure of the game among great powers. But if technology can be a great equalizer, geography is a great un-equalizer. In the geography of Earth, all places are created unequal given their different climates, terrains, resources, and locations. Throughout history, a few places were privileged by these and other factors such as human dynamics, technology, and timing to become the seats of great powers. Uruk, Tjeni, and Magadha, the first great power in Mesopotamia, Egypt, and India respectively, each combined a fertile hinterland and a strategic crossroads of important trade routes. Macedon, Qin, and later, Britain and America shared a similar characteristic: they were supported by a relatively large and resource-rich region and, at the same time, protected by relatively insurmountable geographic barriers-distance, sea, or mountains.

On a larger scale, the Eurasian continent and its adjacent regions in the North Atlantic, North Africa, the Indian Ocean, and the Western Pacific are geopolitically privileged over Earth's other landmasses. Its big size and the diversity of its terrains and climate zones, amplified by its eastwest orientation, have endowed its inhabitants with more resources, great- 
er immunity to pathogens, and better chances of development, as Jared Diamond has vividly described in his book Guns, Germs, and Steel..$^{13}$ The largest among the areas of intense human interaction on Earth, Greater Eurasia was the seat of all great powers throughout history until the rise of the United States at the turn of the 20th century.

From a geopolitical perspective, Greater Eurasia consists of a heartland at its continental core, a rimland that stretches along its western, southern, and eastern seaboards, and some offshore islands such as Britain, Japan, and Java. The primary strategic edge of the Heartland was the superior mobility provided by its steppes and the horse native to this area. However, the Heartland lacked the fertile alluvial soil and the right climatic conditions that made a few Rimland regions - the valleys of the Nile, Euphrates, Tigris, Indus, Ganges, and Yellow River - the birthplaces of the first civilizations and great powers. Throughout history, the Rimland boasts the largest number of inhabitants, production centers, and major powers on Earth. One reason for the productivity of the Rimland is that it has enough water to support life on a very large scale. The productive areas of the Rimland have repeatedly given rise to great powers-Egypt, Assyria, Persia, Rome, India, and China, to name a few-but each remained the hegemon in its own region and never became a global hegemon.

In order to dominate all of the Rimland, one must gain direct access to each of its productive areas, to Europe, the Middle East, India, and China. This geographical imperative gives the hegemonic power of the steppe zone that spans the south of the Heartland from east to west and the hegemonic power of the world's oceans a clear edge over any regional hegemon in the Rimland. The largest contiguous state ever known was the Mongol empire, a great power based in the Heartland which achieved its partial hegemony over Eurasia thanks partly to its central geographic position and the mobility and formidability of its military, both enabled by the Heartland. But the largest state by land area the world has ever had was the British Empire. Based on a large offshore island of Europe, it controlled most of the world's maritime trade routes and dominated the world's oceans, which served as the backbone of its global empire. The Cold War between the Soviet Union and the United States was a direct match of full strength between the hegemon of the Heartland and the hegemon of the maritime domain. The United States emerged victorious from this contest not least because of its favorable geography, which endowed it with a better climate, better protection, and better access to the sea. With direct access to and protection by both the Atlantic and Pacific Oceans, the United 
States was "the most favored state in the world from the point of view of location," as Nicholas Spykman noted on the eve of World War II. ${ }^{14}$ Spykman had refined Halford Mackinder's original idea about the configuration of Earth and developed the concept of the Rimland in conjunction with those of the Heartland and the Offshore. His insights, succinctly summarized in the dictum, "Who controls the Rimland rules Eurasia; who rules Eurasia controls the destinies of the world," would inform much of the U.S. grand strategy in the Cold War, the "containment" strategy. ${ }^{15}$

Offshore powers draw their advantage from the ocean: it provides superior protection and, since the invention of ocean-going ships, supreme connectivity. Like a unified network of gigantic rivers that connects the world's most productive areas, the world's oceans created, before the ages of airplanes and the Internet, the global system of transportation and is still the backbone of this system even when the transportation of goods and data can take place in the air, space, and cyber domains. This advantage of the maritime domain was graphically captured by Alfred Mahan, the author of The Influence of Sea Power upon History 1660-1783, in an early 20th-century debate with Halford Mackinder, the originator of the idea that the "geographical pivot of history" was the Heartland: "As a highway, a railroad competes in vain with a river- the greater speed cannot compensate for the smaller carriage."16

The geographic configuration of planet Earth has a profound impact on almost everything in the biosphere. It dictates the distribution of habitats for animals and plants and constrains the chance of development for nations. ${ }^{17}$ At the geopolitical level, it suggests the seats of great powers and shapes the propensity of great power competition. The specific configuration of land and sea on Earth implies that global hegemony presupposes supremacy in the maritime domain and that among all great powers the biggest Offshore power has the largest chance to obtain this.

\section{IMPLICATIONS FOR THE FUTURE}

\section{A Recurrent Theme}

Great power competition has been a recurrent theme in history since the emergence of the phenomenon in the late 4th millennium BC. Whenever there was more than one great power in a system of states, there was great power competition. In periods of unipolarity, it disappeared from the surface but remained active in various forms of non-peer competition. However, its repeated occurrence, even continuous existence, in the 
past does not guarantee its recurrence in the future. Competition between great powers is unlikely if the expected costs of competition outweigh the expected benefits of predomination.

Nuclear weapons, or more precisely, a large number of nuclear warheads, have rendered an all-out nuclear war prohibitively costly. Nevertheless, great power competition continues to exist in the forms of arms races, proxy wars, and "wars by other means," as we have witnessed since the advent of the nuclear age. Some new technologies in the future-autonomous weapons being one of the candidates - may prove so destructive that they further inhibit war between the great powers, but no technology can eliminate all forms of great power completion. Human ambitions and human ingenuity will find ways for great powers to pursue "low-cost competition" such as indirect warfare, psychological warfare, economic warfare, and other forms of "war by other means."

The geographic configuration of Earth also places a limit on great power competition. Heartland and Rimland powers are heavily disadvantaged against Offshore powers in competition for the dominance of the maritime domain, a sine qua non of global hegemony. But this geographic impediment does not raise the costs of the competition prohibitively high. Thus we will continue to see Rimland and Heartland powers compete with each other and with Offshore powers for mastery over the world's oceans.

Great power competition is nearly identical to hegemonic contest. This is because most great powers prefer their own predominance over a division or sharing of power with competitors. Historical experience can upend this preference and remove the hegemonic contest from a great power competition. The rivalry among Germany, Britain, and France in post-Cold War Europe is a case in point, albeit at the regional level. Leaders and elites of these countries, especially Germany and France, have deeply learned the bloody lessons of World War II, World War I, and the many wars that ravaged Europe in the preceding centuries. This deep historical learning, combined with the fear of a nuclear war, has changed their preference order to $\mathrm{D}>\mathrm{P}>\mathrm{S}>\mathrm{W}$, rendering their power competition a game called "concord," whose only Nash equilibrium is a division of power. When the United Kingdom left the European Union following a referendum in 2016, it did not seek supremacy in Europe, but continued to be committed to a division of power in the region. 
Historical experience is unique to each nation and each region. West Europeans' preference for a division of power over regional hegemony has evolved from their experience with the repeated failure of bids for hegemony, by Habsburg Spain, France, and Germany, and the destructive force of hegemonic wars in the last 500 years. East Asia, the cockpit of the hegemonic contest in the early 21 st century, has a different historical experience. For most of the last 500 years, China was the hegemon in this region with a very few wars waged against Vietnam, Myanmar, and Japan in the south and the east, in part because the Middle Kingdom was focused on conflicts in the north and the west with Inner Asian powers. Perceiving itself as the legitimate overlord of the region, China is dreaming of redressing the "century of humiliation" it suffered at the hands of foreign powers in the 19th and early 20th century and restoring its "rightful" place at the top of the hierarchy of nations. ${ }^{18}$ Hegemonic contest, and not simply great power competition, will stay with us for a long time.

\section{A Game of Chicken}

The "overkill" effect of nuclear weapons requires that a great power in the nuclear age must be a nuclear-armed state. At the same time, it makes direct warfare between great powers more appalling than their own subordination. This change in preference has drastically reduced the number of possible strategic structures for hegemonic contest from nine to two. ${ }^{19} \mathrm{~A}$ hegemonic contest in the nuclear age can take one of two forms: the symmetric game of chicken and an asymmetric game in which a hegemonic contender plays chicken $(\mathrm{P}>\mathrm{D}>\mathrm{S}>\mathrm{W})$ and the major counter-hegemonic powers play concord $(\mathrm{D}>\mathrm{P}>\mathrm{S}>\mathrm{W})$. Lacking a common name by game theorists, I will call this latter game "peace-lover's dilemma" (to be explained below).

The hegemonic contest of our time is centrally between the United States and China. Russia and Islamic fundamentalists are also major global challengers of America but Russia's hegemonic ambition is regional, not global, and the Islamic fundamentalists are not a great power. These "new kids on the block" are a social movement and militant groups seeking to capture the state in countries that have a Muslim majority. The strategic competition between China and the United States is most intense in the Indo-Pacific, where both countries have a part or whole of their territory. The system-makers of this region include America, China, and to a lesser extent, India and Japan. 
As seen in the previous sections, different preference orders of the players create different structures of their strategic game, which profoundly affects the best strategies they can pursue and the stable outcomes of their game. The sense of entitlement for supremacy is deeply ingrained in the Chinese psyche and finds its policy expression in the "China Dream"rejuvenation of the Chinese nation and restoration of China's supreme position in the international system. This dual goal has been embraced and pursued by successive generations of Chinese leaders regardless of their political orientation for more than a hundred years, from Sun Yat-sen to Chiang Kai-shek and Mao Zedong, to Deng Xiaoping, Jiang Zemin, Hu Jintao, and now Xi Jinping. ${ }^{20}$

With regard to nuclear weapons, after a brief period thinking that China's massive population could help the country survive major nuclear attacks, Chinese leaders realized that with a sufficient nuclear arsenal, a country can deter major attacks from its nuclear-armed enemies. ${ }^{21}$ China's preference order in its hegemonic contest is, therefore, that of a chicken game player $(\mathrm{P}>\mathrm{D}>\mathrm{S}>\mathrm{W})$; indeed, China has played the game of chicken masterfully. 22

The nuclear taboo- - the thinking that nuclear war is morally unthinkable- is even more entrenched in the United States. ${ }^{23}$ But America is less determined than China in pursuing international primacy. The United States has fundamentally two strategic choices. If it prefers its predominance over a division or sharing of power with China, its preference order will be that of a chicken game player, and the game it plays with China will be the symmetric game of chicken. But if it prefers a division or sharing of power with China over its own supremacy, its preference order will be that of a concord game player $(\mathrm{D}>\mathrm{P}>\mathrm{S}>\mathrm{W})$ and the game it plays with China will be the asymmetric game I call "peace-lover's dilemma." It is a dilemma for the game's peace-loving players because the game's only Nash equilibrium - its stable outcome-is the dominance of the more aggressive (the chicken game player) over the less aggressive (the concord game player). ${ }^{24}$ The less aggressive strategy of the concord game player has eliminated two of the three Nash equilibria of the symmetric game of chicken, leaving only one stable outcome for the asymmetric game. As this game is ultimately unfavorable to the United States, Washington is - after learning it the hard way-behaving more like a chicken game player than a concord game player. Indeed, the strategic imperative of the hegemonic contest with China is that America prefers its own supremacy over sharing power with China. 
According to the logic of the chicken game, World War III is unlikely to occur, although high tensions and dangerous crises will abound and localized, conventional conflicts are possible. The structure of the game entails that none of its three Nash equilibria is a Thucydides trap. If both players in the prisoner's dilemma are bound to clash, they are bound to avoid their clash in the game of chicken. With regard to strategy, if one side escalates and the other side de-escalates, the more aggressive side will gain and the gains tend to be frozen into the status quo. But if both sides escalate, they will eventually reach some sort of agreement, expressly or tacitly. Knit together, these agreements will form a division of power between the main contenders, creating their spheres of influence in the major domains of the contest.

How should the United States behave when China is assertive and escalating? One option, as many have advocated, is to concede to China what it claims to be its core interests, avoid confrontation with Beijing, and if push comes to shove, share power with China or simply abandon the pursuit of Pax Americana. ${ }^{25}$ This strategic choice will effectively turn the symmetric game of chicken into the asymmetric peace-lover's dilemma. It remains a sensible strategy for one of the chicken game's three Nash equilibria - but the worst of the three for America. A better strategy that can prevent both war and Chinese dominance is holding the line when China is testing your resolve and matching its escalation with your own while maintaining a channel for talks.

Assertiveness pays off in the game of chicken. As China has brilliantly shown in practice, this "aggressive but not very aggressive" kind of action operates in the gray zone between war and peace. Gray zone approaches play on the gap between the fluid nature of reality and the rigid character of rules, norms, and conventions. This gray zone has three dimensions, and a master player of the game of chicken must leverage all three dimensions of the gray zone, in tactics such as fait accompli, salamislicing, and "cabbage" - surrounding a target like a cabbage wrapping itself with layers of non-military forces on the front and paramilitary forces in the middle, supported by military forces over the horizon. Based on the principles of deniability, camouflage, stealth, indirection, gradualism, and fait accompli, these tactics and others that will be invented or reinvented will gain strategic importance in the coming decades.

As kinetic war becomes too risky in the nuclear age, war by other means, such as political warfare, information warfare, psychological warfare, economic warfare, "lawfare" (the use of law as a weapon of conflict), 
and the weaponization of the non-military-the media, tourists, universities, relationships, international organizations, to name just a few-will be critical to future power competition. ${ }^{26}$ An effective tactic in the game of chicken is "riskfare," as exemplified by China in its recent "assertiveness." 27 Riskfare is the deliberate use of risks that plays on the opponent's fear of escalation. As the fear of escalation tends to spread more freely and more quickly in open societies and smaller countries, China has a strong edge in weaponizing risks to achieve its objectives without the use of kinetic force.

\section{The Winning Geography}

The symmetry of the game of chicken or the prisoner's dilemma refers to the symmetry of the players' preference orders, not that of their capacities. Although states can reach parity in economic output or weapons arsenals, they remain unequal with respect to location. As we have seen in a previous section, a significant part of a state's capacity comes from its position in the configuration of Earth. The U.S.-China competition shares its strategic structure - the chicken game-with the Cold War, but it is unprecedented regarding its configurative structure. While the Soviet Union was a Heartland power, China is a Rimland power. As Offshore vs. Rimland struggles, the Britain vs. France competition of the late 18th and early 19th centuries and the Britain vs. Germany rivalry in the early 20th century are nearer to the Sino-U.S. contest in this respect. But the geography of Europe is radically different from that of Asia. In terms of configurative structure, the nearest precedent to the present great power competition in Asia is the concurrent rivalry between Japan and China and between Japan and Russia in the late 19th and early 20th centuries. But if Japan, an Offshore power, was the rising power at that time, it is China, a Rimland power, that is rising this time.

Today the lifeline of Asia, which carries more than half of the region's trade, is the waterways that run through the East China Sea, the South China Sea, and the northeastern section of the Indian Ocean. About $90 \%$ of the crude oil imported by China, Japan, and South Korea, nearly two-thirds of South Korea's energy supplies, around 60\% of Japan's and Taiwan's energy supplies, and four-fifths of Southeast Asia's international trade are shipped through the South China Sea alone. ${ }^{28}$ As the world's economic center of gravity is shifting to Asia, where $60 \%$ of the world's population lives, to paraphrase Spykman, who controls the Western Pacific and the Eastern Indian Ocean rules Asia; who rules Asia controls 
the destinies of the world. A number of places are critical to the control of these waterways because they dominate the chokepoints of these sea lines of communication. They are-from northeast to southwestJapan, South Korea, China, Taiwan, the Philippines, Vietnam, Malaysia, Singapore, Indonesia, Australia, India, Sri Lanka, the Maldives, and the Chagos Archipelago (the British Indian Ocean Territory). Among these places, Japan, India, Taiwan, and Indonesia, given their locations and their resources, hold the key to the balance of power between China and the United States. If China expands its sphere of influence to the rest of Asia but these four stay closer to the United States, then the world balance of power can still tilt toward the latter. A principal imperative for the United States as well as for China in their strategic contest is to gain influence in and access to these places.

\section{New Kids on the Block}

In the last 500 years at least, technological and economic changes advanced in waves and were in close relationship with the cycle of hegemonic conflict. ${ }^{29}$ Each of the past waves of the Industrial Revolution was accompanied by a hegemonic struggle: the First, by the Napoleonic Wars; the Second, by World Wars I and II; and the Third, by the Cold War. Starting after the Cold War, the Fourth Industrial Revolution is now also accompanied by the hegemonic contest between China and the United States. Since the Second Industrial Revolution, each wave of the Industrial Revolution has made a new domain available to human activities: the Second added the air domain to the land and maritime domains, the Third opened up the space domain, the Fourth created the cyber domain.

Already indispensable for human life and a critical domain of human activities, the cyber domain has become a lifeline during the COVID-19 pandemic, carrying much of human communications and social activities - tens of millions of people depend on it when working from home or in lockdown. The Fourth Industrial Revolution, with its reliance on mobile networks and the Internet of Things, is making the cyber domain essential for economics, politics, and security. In some respects, it has become more important than the air and space domains because it carries information that everyone relies on. Human communications and social activities are present in the form of data in the cyber domain. These data can be collected, controlled, and manipulated by those that provide the applications, devices, physical networks, and virtual platforms for the com- 
munications and activities to take place. As it stands today, a small number of "Big Tech" companies dominate the markets for these goods and services. Their access to data and devices and their control of networks and platforms make them critical actors in the geopolitical system. These "new kids on the block" have the power to change the system, though the power to make the system still lies in the hands of great powers.

Together with the maritime domain, the cyber domain provides a central theater of contest for the hegemonic contenders of our time. Today, the division of the cyber domain into a Chinese sphere of influence and a U.S. sphere of influence is well underway, with Huawei, the world's largest producer of $5 \mathrm{G}$ equipment, leading the effort to enlarge the Chinese sphere of influence. Like the British East India Company, Huawei is a private company that expands the power of its sovereign by conquering vast and critical areas, this time in the physical layer of the cyber domain. Nonexistent before the 1990s, the cyber domain is virtual but not nonphysical because it has a physical layer upon which the networks are built. Spheres of influence in this physical layer often reflect and reinforce those in the land domain. Once established, they are far harder to change than spheres of influence in the maritime domain and the virtual space of the cyber domain.

\section{CONCLUSION}

Great power competition is inherent in the phenomenon of great powers - as long as there are great powers in a system of states, there is competition between them. Underlying this phenomenon are human dynamics such as the concentration of power and the ambitions of individuals. Although great powers are the makers of the international systems, their rise and fall and the balance of power among them are heavily affected by the system-changers, who are not necessarily state actors but gain their advantage from the extraordinary dynamism of their quest of opportunities, which sometimes manifests in their superior mobility, their organizational flexibility, or their frontier position in a critical domain.

There are three major kinds of structures that shape the relations between great powers. The first includes the belief systems of the elite and the populace. They mold their thought and guide their action, thus directly impact the course and the strength of the state. In the form of historical experience and ideology, beliefs can profoundly shape and change the character of great power relations. The second is the strategic structure 
that emerges from the interaction of the preference orders of the great powers involved. This strategic structure ensures that some outcomes of the competition are more stable than others and some strategies of the contenders are more viable than others. Understanding the strategic structure of great power competition will help us answer key questions related to war and peace and strategy. Thirdly, great power competition is also structured by geography. The configuration of land, sea, and terrain on Earth gives the arena of great power competition a distinctive form. Reflecting the locations of the great powers, the production centers, the transportation routes, and the geographical barriers, the configurative structure of great power competition also restricts—and enables- the capabilities and strategies of the great powers. It suggests that, more than any great power in the Heartland and Rimland of Eurasia, the biggest Offshore power has the best chance to achieve global primacy.

The advent of nuclear weapons has required that a great power be a nuclear-armed state. This frightening fact has eliminated the structural cause of war between the great powers - a "trap" famously noted by the 5th-century BC Greek historian Thucydides in his comment on the inevitability of war between the hegemonic contenders of his time and place. However, the risk of war still exists in human errors, machinery defects, and some idiosyncratic factors. Beliefs - the first kind of structures mentioned above — can help humanity to minimize the risks of a nuclear holocaust.

\section{Acknowledgment:}

I am grateful to Long Vuving for his research assistance and insights, which have broadened my horizons and helped to refine my arguments. I also wish to thank Carleton Cramer, Mary Markovinovic, and Tami Rosado for their valuable comments on an earlier draft of this paper. 


\section{Notes}

1 Toby Wilkinson, The Rise and Fall of Ancient Egypt (London: Bloomsbury, 2010). Harriet Crawford, ed., The Sumerian World (New York: Routledge, 2016).

2 Gérard Chaliand, A Global History of War: From Assyria to the Twenty-First Century, trans. Michèle Mangin-Woods and David Woods (Oakland, CA: University of California Press, 2014), 100-107.

3 See boxes for some examples of system-changers and John Haywood, ed., Atlas of World History (New York: Fall River Press, 2009) for brief discussions of these groups in the context of world history.

4 For example, Christopher Layne, "The Unipolar Illusion: Why New Great Powers Will Rise," International Security 17, no. 4 (Spring 1993): 5-51; Kenneth N. Waltz, "The Emerging Structure of International Politics," International Security 18, no. 2 (Fall 1994): 44-79; Christopher Layne, "The Unipolar Illusion Revisited: The Coming End of the United States'Unipolar Moment," International Security 31, no. 2 (Fall 2006): $7-41$.

5 For example, William C. Wohlforth, "The Stability of a Unipolar World," International Security 24, no. 1 (Summer 1999): 5-41.

6 A number of events between 2008 and 2016 marked the end of the unipolar period and the beginning of a U.S.-China bipolar era. Shortly after the 2008 financial crisis, China overtook the United States as a leading trade partner of most countries, including many U.S. allies such as Japan, South Korea, and Australia. See Alyssa Leng and Roland Rajah, "Chart of the Week: Global Trade through a US-China Lens," The Interpreter, Lowy Institute, December 18, 2019, https://www.lowyinstitute.org/theinterpreter/chart-week-global-trade-through-us-china-lens. When China set up the Asian Infrastructure Investment Bank in 2015, several U.S. allies, including Australia, South Korea, the United Kingdom, Germany, and France, applied to join it despite U.S. opposition. China and Russia formally declared a "comprehensive strategic and cooperative partnership" in 2011. The same designation had been awarded to China's relationship with Vietnam in 2008, Laos in 2009, Cambodia in 2010, and Myanmar in 2011. Beijing and Moscow formally upgraded their relations to "comprehensive strategic and cooperative partnership for a new era" in 2019.

7 For George W. Bush's view of China as a "strategic competitor," see his campaign remarks in 1999 and 2000: George W. Bush, "A Distinctly American Internationalism," speech at the Ronald Reagan Presidential Library, Simi Valley, California, November 19, 1999, https://www.mtholyoke.edu/acad/intrel/bush/wspeech.htm; and George W. Bush in CNN, Larry King Live Show, South Carolina Republican Debate, aired on February 15, 2000, transcript at http://transcripts.cnn.com/TRANSCRIPTS/0002/15/lkl.00.html. Hinting at China, the Quadrennial Defense Review Report (QDR) of the U.S. Department of Defense, dated September 30, 2001, noted, "The possibility exists that a military competitor with a formidable resource base will emerge in the region. The East Asian littoral - from the Bay of Bengal to the Sea of Japan - represents a particularly challenging area" (p. 4). The QDR identified "[p]recluding hostile domination of critical areas, particularly Europe, Northeast Asia, the East Asian littoral, and the Middle East and Southwest Asia" as one of the "enduring national interests" of the United States (p. 2), https://archive.defense.gov/pubs/ gdr2001.pdf. A year later, the National Security Strategy of the United States of America (NSS) issued by the Bush administration in September 2002 directed the focus on the "war on terror" and emphasized "strengthen[ing] alliances to defeat global terrorism" and "develop[ing] agendas for cooperative action with other main centers of world power" (pp 1-2). On China, the NSS stated, "We welcome the emergence of a strong, peaceful, and prosperous China" and "The United States seeks a constructive relationship with a changing China" (p. 27), https://2009-2017.state.gov/documents/organization/63562.pdf.

8 Chinese President Jiang Zemin stated in 2002 that the following 20 years would be a "period of strategic opportunity" for China to develop its comprehensive 
national strength, international competitiveness, and global influence due to a favorable strategic environment. See Jiang Zemin, "Build a Well-off Society in an All-Round Way and Create a New Situation in Building Socialism with Chinese Characteristics," report delivered at the 16th National Congress of the Communist Party of China, Beijing, November 8, 2002, https://www.fmprc.gov.cn/mfa_eng/ topics_665678/3698_665962/t18872.shtml and Xu Jian, "Rethinking China's Period of Strategic Opportunity," China International Studies (March/April 2014): 52. China's gross domestic product in 2001 is estimated at US\$ 2.418 trillion, while the figure for 2016 is US\$ 9.524 trillion; both are in constant 2010 US\$, according to the World Bank's data: https://data.worldbank.org/indicator/NY.GDP.MKTP. $\mathrm{KD}$ ?locations $=\mathrm{CN}$.

9 Thucydides, The History of the Peloponnesian War, translated by Richard Crawley, https://www.gutenberg.org/files/7142/7142-h/7142-h.htm.

10 Andrew M. Colman, Game Theory and Its Applications: In the Social and Biological Sciences (New York: Routledge, 2017).

11 For names of games and their preference orders, see the "periodic table" of strategic games in Bryan Randolph Bruns, "Names for Games: Locating 2x2 Games," Games no. 6 (2015): 495-520.

12 The fullest statement of the Thucydides Trap thesis is Graham Allison, Destined for War: Can America and China Escape Thucydides's Trap? (Boston: Houghton Mifflin Harcourt, 2017). Allison explains the four "no-war" anomalies by recourse to a plethora of ad hoc factors ranging from the Pope's authority, to economic, political, and security institutions, to the role of statesmen, timing, cultural commonalities, to nuclear weapons and economic interdependence (pp. 187-286). From the perspective of Occam's razor, Allison's explanations are clearly inferior to an explanation based on the strategic structure of hegemonic contest.

13 Jared Diamond, Guns, Germs, and Steel: The Fate of Human Societies (New York: W.W. Norton, 1999).

14 Nicholas J. Spykman, "Geography and Foreign Policy, I," American Political Science Review 32, no. 1 (February 1938): 43.

15 Antero Holmila, "Re-thinking Nicholas J. Spykman: From Historical Sociology to Balance of Power," The International Historical Review, 2019, https:/ / www.tandfonline.com/doi/full/10.1080/07075332.2019.1655469. The quote is in Nicholas John Spykman, The Geography of the Peace (New York: Harcourt, 1944), 43.

16 A.T. Mahan, The Influence of Sea Power upon History, 1660-1783 (Boston: Little, Brown, and Company, 1898). H.J. Mackinder, "The Geographic Pivot of History," The Geographical Journal 23, no. 4 (April 1904): 421-444. The quote is in A.T. Mahan, The Problem of Asia and Its Effect upon International Policies (Boston: Little, Brown, and Company, 1900), 38.

17 Diamond, Guns, Germs, and Steel.

18 Howard W. French, Everything Under the Heavens: How the Past Helps Shape China's Push for Global Power (New York: Alfred A. Knopf, 2017).

19 The nine strategic structures of hegemonic contest include the three symmetric games of deadlock, chicken, and the prisoner's dilemma, the three asymmetric combinations of these three, and the three asymmetric variants of the "stag hunt" pairing with either the prisoner's dilemma, deadlock, or chicken.

20 Orville Schell and John Delury, Wealth and Power: China's Long March to the TwentyFirst Century (New York: Random House, 2013). Friso M.S. Stevens, "China's Long March to National Rejuvenation: Toward a Neo-Imperial Order in East Asia?" Asian Security (2020), https://www.tandfonline.com/doi/full/10.1080/14799855.2020.1739 651. 
$21 \mathrm{Xu}$ Weidi, "China's Security Environment and the Role of Nuclear Weapons," in Understanding Chinese Nuclear Thinking, eds. Li Bin and Tong Zhao (Washington, DC: Carnegie Endowment for International Peace, 2016). M. Taylor Fravel and Evan S. Medeiros, "China's Search for Assured Retaliation," International Security 35, no. 2 (2010): 48-87.

22 Alexander L. Vuving, "The Strategic Environment of the US-Australia Alliance in the Indo-Pacific Era," in The Future of the US-Australia Alliance: Evolving Security Strategy in the Indo-Pacific, eds. Andrew T. H. Tan and Scott D. McDonald (London: Routledge, 2021).

23 Nina Tannenwald, The Nuclear Taboo: The United States and the Non-Use of Nuclear Weapons Since 1945 (Cambridge: Cambridge University Press, 2007).

24 Bruns, "Names for Games," 499.

25 For example, Allison, Destined for War, 235-238; Hugh White, The China Choice: Why America Should Share Power (Oxford: Oxford University Press, 2013).

26 Qiao Liang and Wang Xiangsui, Unrestricted Warfare (Beijing: PLA Literature and Arts Publishing House, 1999), translated by FBIS, https:// www.c4i.org/unrestricted. pdf. Alexander L. Vuving, "China's Strategic Messaging: What It Is, How It Works, and How to Respond to It," in China's Global Influence: Perspectives and Recommendations, eds. Scott D. McDonald and Michael C. Burgoyne (Honolulu: Daniel K. Inouye Asia-Pacific Center for Security Studies, 2019), https:/ /apcss.org/wp-content/ uploads/2019/09/10-Chinas_strategic_messaging-vuving.pdf. Robert D. Blackwill and Jennifer M. Harris, War by Other Means: Geoeconomics and Statecraft (Cambridge, MA: Harvard University Press, 2016).

27 Jonathan G. Odom, “China's 'Riskfare," Proceedings (of the United States Naval Institute) 145, no. 3 (March 2019): 1,393.

28 China Power Team, "How Much Trade Transits the South China Sea?" China Power, August 2, 2017, updated October 10, 2019, https://chinapower.csis.org/ much-trade-transits-south-china-sea/. Robert D. Kaplan, Asia's Cauldron: The South China Sea and the End of a Stable Pacific (New York: Random House, 2014), 9. U.S. Energy Information Administration, "More than 30\% of Global Maritime Crude Oil Trade Moves through the South China Sea," Today in Energy, August 27, 2018, https://www.eia.gov/todayinenergy/detail.php?id=36952.

29 Joshua S. Goldstein, Long Cycles: Prosperity and War in the Modern Age (New Haven: Yale University Press, 1988). 
